XXIX.-Aspects of the Body in Vertebrates and Arthropods. By A. S. PACKARD*

Under the title 'Aspects of the Body in Vertebrates and Invertebrates' (London, 1883) the venerable and distinguished English anatomist and palæontologist, Professor Sir Richard Owen, renews in a vigorous way the old discussion originally begun by Geoffroy St.-Hilaire. 'The view in question is tersely presented in St. Hilaire's answer to Dugès, quoted by Professor Owen, when he replied by reference to "Fig. 2 de la septième planche: Là se trouve effectivement représenté un homard couché sur le dos et montrant distinctivement ses viscères dans la position où le sont les viscères des mammifères placés sur le ventre." This view was combated by Cuvier, and in this respect he has been followed by Gegenbaur.

In his able essay Professor Owen places himself on the side of St.-Hilaire, and the special point in vertebrate anatomy which he brings forward to support this opinion is the homology of the conario-hypophysial tract, which he regards as " the modified homologue of the mouth and gullet of invertebrates ;" and at the end of chapter i. he concludes that "the surfaces or aspects of the body which are truly homologous in the snake and caterpillar are the neural and the homal, not the dorsal and the ventral."

In his second chapter, entitled "Cerebral Homologies in Vertebrates and Invertebrates," Professor Owen quotes our statement $\dagger$ that "the brain and nervous cord of the fish or man is fundamentally different, or not homologous with that of the lower or invertebrate animals," and then proceeds to criticize it.

'The chapter on the brain of the locust was written for the unscientific as well as the scientific reader, and the introductory part was presented in a terse, perhaps dogmatic way, for the sake of clearness.

The author, without taking time and space to discuss at length this broad question, which requires a far wider acquaintance with anatomy and embryology than he claims to possess, would beg leave to briefly present some facts and considerations which seem to him to support the view he adopted as to the lack of homology between the nervous system of Arthropods and Vertebrates.

* From advance sheets of the 'American Naturalist,' Sept. 1884, pp. 85.5-861, communicated by the Author.

† Second Report U. S. Entomolngical Commission, chap. xi., "The Brain of the Locust," p. 224 (1880). 
These facts relate to the histology and the histological topography as well as the general morphology of the system in question, and to the general relation of the viscera to the bodywalls of Arthropods as compared with Vertebrates.

1. Histology.-There are but two histological elements in the brain and spinal cord of Vertebrates, $i$. e. ganglion-cells and nerve-fibres proceeding from them. In Worms (and Mollusks so far as known) and especially in the brain (procerebrum, as we may call it to distinguish it from the cerebrum of Vertebrates) and other ganglia of Crustacea and insects, besides these two elements there is a third substance, the Punlitsubstanz, discovered by Leydig, and further described by Dietl and Krieger, and for which we would suggest an English equivalent, the myeloid substance.

2. Histological Topography-The arrangement of the ganglion-cells and other tissues in the ganglia of Arthropods is not homologous with that of Vertebrates. In the brain or any of the postœesophageal ganglia of Arthropods there is a central mass formed of the myeloid substance, which is enveloped by a cortical layer of mostly unipolar ganglion-cells. The fibres from the ganglion-cells pass into and emerge again from the myeloid substance, which is a tangled mass of minute fibrillæ. The fibres from certain of the ganglion-cells we have clearly seen to pass through or over the myeloid substance and to form both the transverse commissures of the brain and also the two main longitudinal commissures connecting the chain of ganglia. But the fibres from the majority of the ganglion-cells appear, as Leydig holds, to break up into the tangled mass of extremely fine fibres, which, when cut through, presents a dotted or granulated appearance. This myeloid substance remains unstained, while the ganglion-cells readily stain by reagents.

In the brain and other ganglia of vertebrates, on the other hand, the ganglion-cells are internal, the fibres arising from uni-, bi-, or multipolar ganglion-cells passing outside. In Invertebrates, at least in Arthropods, there is no "white" or "grey" substance; none such has been described by Leydig. or the later students of the central nervous system of Arthropods.

Histogenesis.-If we look at the genesis of the ganglia of Arthropods, we see that they consist at first wholly of spherical cells, the fibres and myeloid substance being secondary products, and their position is not homologous with that of the ganglia in vertebrate embryos. The reader is referred to fig. 246 in Balfour's ' Comparative Embryology' vol. ii. p. 343. 'The section of the spinal cord of a seven-days' chick 
there figured shows that the cord is early differentiated into the internal grey mass, consisting of round cells, enveloping the spinal canal, while the cortical white substance or column surrounds the mass of ganglion-celis. In the Annelidan worms and the Arthropods the embryonic ganglion is a much simpler structure, consisting of a mere mass or ball of ganglion-cells with incipient fibres passing from them. Certain of these fibres grow longer, forming the commissures, trans verse and longitudinal, connecting the ganglia. At first, then, the nervous system of the higher worms (those with a ganglionated chain) and Arthropods consists of a series of disconnected ganglia, which eventually become connected by secondary products, the commissural fibres. The fact that in Worms the brain is at first separated from the rest of the ganglia, as stated in Balfour's 'Embryology' (i. p. 291), is not of particular significance, since all the ganglia, at least in Crustacea and insects, are at first disconnected from each other.

Embryology appears to give no countenance to the view held by some authors that the brain of an Arthropod may represent the nervous system of the Vertebrate, and the postœsophageal chain of ganglia the sympathetic system of the Vertebrates.

There seems to be a unity of plan, so to speak, in the development of the nervous system of the Arthropods, and how

Fig. 1,
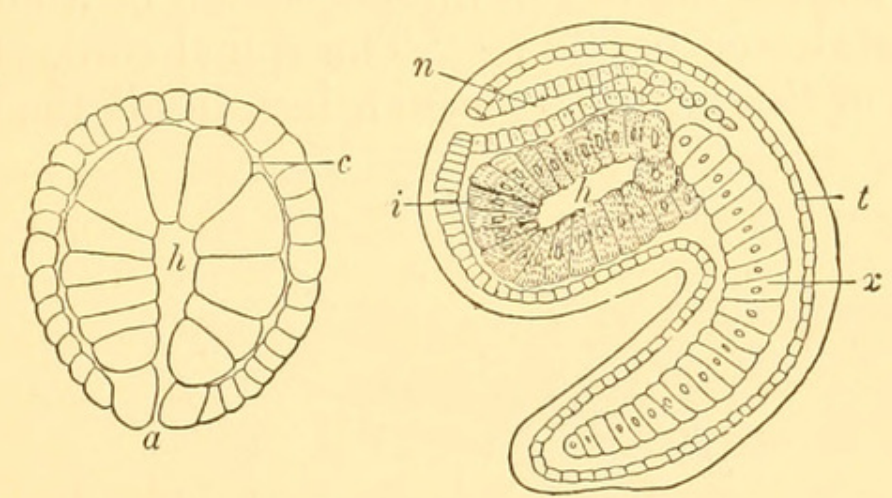

Early stage of Ascidian embryo, showing the nervous tube $n$, open in front and situated dorsally above the alimentary tube $(h)$, as in Vertebrates.

radically different that is from the mode of genesis of the vertebrate nervous system may be seen by reference to Balfour's work (ii. pp. 250-252) or those of other observers. While the nervous system of all animals arises from the ectoderm (epiblast), as Balfour states: "In all Chordata an axial strip of the dorsal epiblast, extending from the lip of the 
blastopore to the anterior extremity of the head, and known as the medullary plate, becomes isolated from the remainder of the layer to give rise to the central nervous axis ;" in T'unicates as well as Vertebrates this plate is converted into a tube or canal, which lies wholly above the alimentary tract. It is this striking feature in embryo Tunicates which mainly seems

Fig. 2.

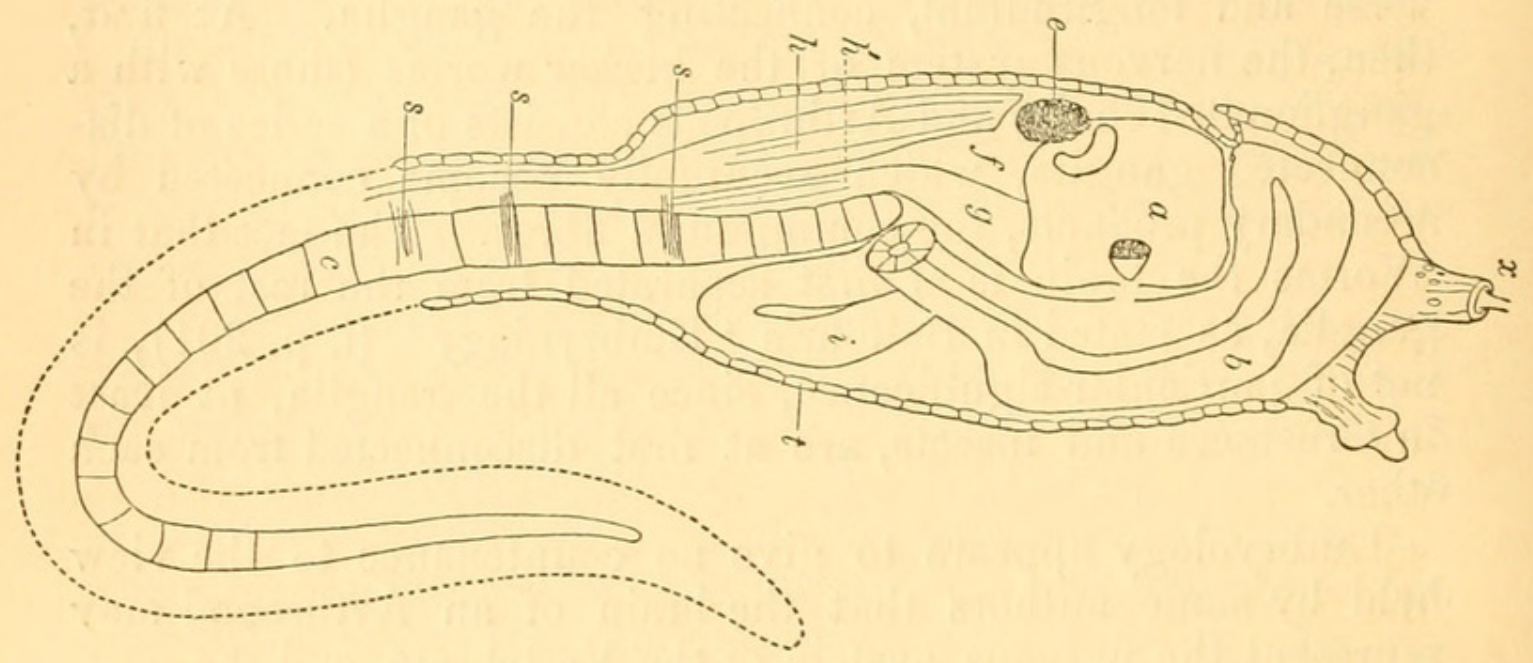

Embryo of an Ascidian, showing the vertebrate plan of structure; the nervous system $\left(h^{\prime}, h\right)$ with the spinal nerves $(s)$ being situated dorsally above the notochord $(c)$ and alimentary canal $(b, i)$.

to justify their elimination from the Worms and indicates their proximity to the Vertebrates, as this seems to be a more truly vertebrate feature than even the possession of a notochord.

Balfour states on p. 342 :- "The spinal cord, shortly after the closure of the medullary canal, has, in all the true Verte-

Fig. 3.

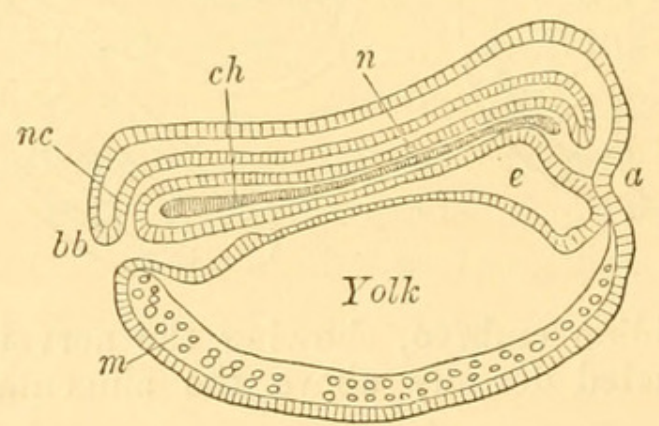

Section of a vertebrate embryo (a fish): $n$, nervous tube, open in front and situated dorsally; ch, notochord; $b b$, mouth; $e$, alimentary canal; $a$, place of vent; $m$, mesoderm.

brata, the form of an oval tube, the walls of which are of a fairly uniform thickness, and are composed of several rows of elongated cells. This cord, as development proceeds, usually 
becomes vertically prolonged in transverse section, and the central canal which it contains also becomes vertically elongated." Then follows the differentiation (1) of the epithelium of the central canal, (2) of the grey matter of the cord, and (3) of the internal coating of white matter. "The white matter is apparently the result of a differentiation of the outermost parts of the superficial cells of the cord into longitudinal nerve-fibres, which remain for a long period without a medullary sheath. .... . The grey matter and the central epithelium are formed by a differentiation of the main mass of the spinal cord."

There thus appears to be a lack of homology in the histological topography and origin of the nervous system in Chordata as compared with the Annelidan worms and the Arthropods.

The relation of the nervous system of Arthropods is constant; after the stomodæum has been formed, commissures from the brain pass down and connect the latter with the subœsophageal ganglion, which is ventral. This relation of the postoesophageal nervous system to the ventral side of the

Fig. 4.

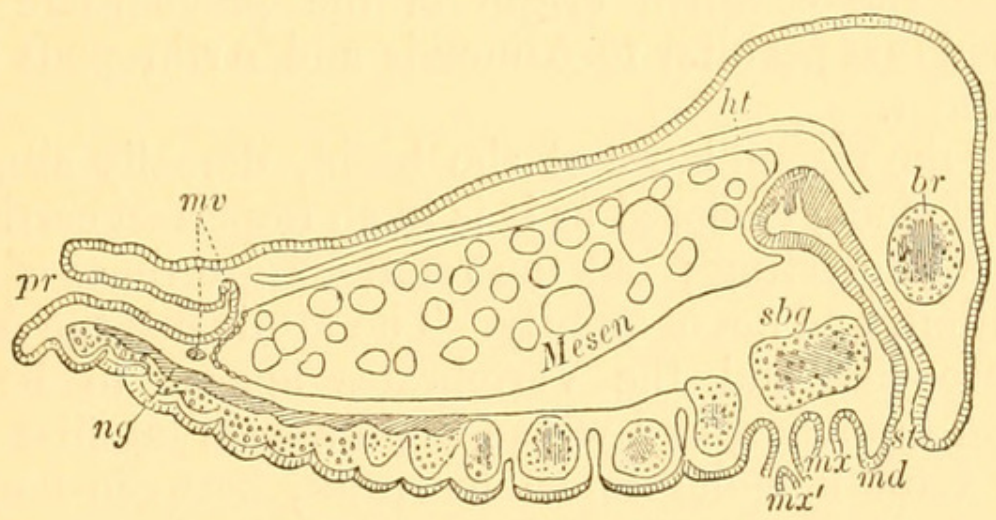

Relations of the nervous system of an embryo (Orthopterous insect to the body-walls: $b r$, brain; sbg, subœsophageal ganglion; $n g$, nervous cord; st, stomodæum; pr, proctodæum; mv, malpighian tubes; mesen, mid-intestine; ht, heart; $m d$, mandibles; $m x, m x^{\prime}$, 1st and 2nd maxillæ. From Ayers, with changes.

body is as constant as the disposition of the ventral surface of the embryo of Insects before the revolution of the embryo, or of the embryos of Annelid worms and Crustacea. The position of the Arthropod embryo is the reverse of that of Vertebrates. The vertebrate disposition of the primitive nervous system is also seen in the embryo Tunicate (figs. 1, 2). Morphology.-The brain of the Arthropoda is contained in a structure which throughout is lacking in homology with 


\section{Aspects of the Body in Vertebrates and Arthropods.}

that of Vertebrates. The crust, the segments, and the appendages especially have nothing in common with Vertebrates, though the functions are in a degree the same. The origin and homologies of the sensory organs are $a b$ initio different. For example, the eyes of Arthropods are not truly homologous with those of Vertebrates; the cornea is simply a number of epithelial cells, while in Vertebrates the eye externally is an ingrowth of the epiblast. As the wings and legs of insects and organs of hearing and of smell are not the homologues of the parts which function as such in Vertebrates, so we are not inclined to regard the heart and nervous system of Arthropods as truly homologous with the corresponding organs of Vertebrates. If there is such a fundamental difference in the two types as regards the relations of the viscera to the body-walls, and if this relation is common to all Arthropods and the Annulata, we shall have to go back to the hypothetical common ancestors of the Tunicates and Vertebrates on the one hand, and of the Annulata and Arthropoda on the other, for the means of comparison. It is not impossible that in animals allied to the Planarian or Nemertean worms, whose nervous system consists of a pair of dorsal ganglia, with two or more pairs of nerves passing backward, that the common origin of the prochordate nervous system and that peculiar to Annelids and Arthropods may yet be discovered.

So also the resemblance of the brain, dorsally situated, of the Cephalopods, enclosed as it is in an imperfect cartilaginous capsule, is interesting; but the relations are those of analogy or adaptation, and not of affinity. The Mollusks, the Annelids, the Arthropods, and the Vertebrates appear to be highly specialized branches, and where there appear at first sight to be direct cross-homologies, so to speak, between them, these are rather independent structures, the result of adaptation rather than of direct descent. Examples of such, we believe, are the eye, the brain, and the heart of the Cephalopods.

The unity of organization in the animal world is seen rather in the homology of the cellular structure and in the common origin of all from unicellular forms, and among the Metazoa in the identity of the morula and gastrula conditions, or at least the germ-layers; and as regards the ne:vous system, in its origin in the epiblast, rather than in any special parts or organs of such highly elaborated and specialized types as are represented by the lobster, or butterfly, or tish.

The dispute between Cuvier and St.-Hilaire and their followers was in part metaphysical. The old-time problems in transcendental anatomy, such as comparing a lobster to a 
vertebrate upon its back, the problems of fore-and-aft symmetry, and the question of torsion in the fore and hind limbs of Mammals, have, if we are not mistaken, lost much of their interest and value in the light of modern evolutionary problems, and savour more of scholasticism than of science.

At all events the present problem is, as embryology shows, so remote in its bearings, - the common point of origin of Arthropod and Vertebrate, the fork in the primitive developmental path where the two branches began to diverge, is set so far back in the animal scale, and is so remote in geological time, that with our present knowledge we are inclined to regard the consideration of such problems as belonging rather to metaphysics than to pure science, although it should be granted that further researches among the lower worms may yet result in the discovery of facts bearing upon the origin of the singular differences in the disposition of the arthropod and vertebrate nervous systems.

In conclusion, therefore, we are led to endorse the following opinion of Gegenbaur, in his ' Comparative Anatomy' (English translation):- "The greater size of the cephalic ganglion compared with that of the ventral ganglia has been already seen in many of the Annulata; in the Arthropoda it is ordinarily still more distinct; this condition may be partly explained by its relations to the more highly developed organs of sense, if we recognize in the dorsal cesophageal ganglion something similar to the brain of the Vertebrata. Led by an idea of this kind, some have compared even the ventral ganglia or ventral medulla with the dorsal medulla of the Vertebrata, and have striven to carry the comparison still further; these attempts ignore the complete difference between the type of structure of the Arthropoda and of the Vertebrata" (p. 252).

XXX.-A Contribution to the Knowledge of the Freshwater Sponge Dosilia Stepanowii. By Dr. M. Dy Bowski*.

In the description of the freshwater sponge, Dositia? Stepanowiit, recently published by me, I lett its gemmules entirely out of consideration, because none were present in the

* Translated by W. S. Dallas, F.L.S., from the " Zoologischer Anzeiger,' no. 175 , Septen ber 1, 1884, p. 476.

† Dybowski, "Notiz über die aus Süd-Russland stammenden Spongillen," in Sitzungsb. d. naturf. Gesellsch. d. Univ. Dorpat, Band vi. p. 507 (translated in this journal for July 1884, p. 58), and 'Travaux de la Société des Naturalistes de l'Université de Chalkow,' vol, xvii. (1883), p. 289, pl, vii, fig. $1 a-d$, in Russian. 


\section{$2 \mathrm{BHL}$ Biodiversity Heritage Library}

Packard, A. S. 1884. "XXIX.-Aspects of the body in Vertebrates and Arthropods." The Annals and magazine of natural history; zoology, botany, and geology 14, 243-249. https://doi.org/10.1080/00222938409459802.

View This Item Online: $\underline{\text { https://www.biodiversitylibrary.org/item/53345 }}$

DOI: https://doi.org/10.1080/00222938409459802

Permalink: https://www.biodiversitylibrary.org/partpdf/51440

\section{Holding Institution}

Smithsonian Libraries

\section{Sponsored by}

Smithsonian

\section{Copyright \& Reuse}

Copyright Status: Public domain. The BHL considers that this work is no longer under copyright protection.

This document was created from content at the Biodiversity Heritage Library, the world's largest open access digital library for biodiversity literature and archives. Visit BHL at https://www.biodiversitylibrary.org. 